\title{
Environmental Issues in the Mining Sector of Mongolia
}

\author{
Ikhbayar Batmunkh \\ Mongolian Association of Environmental Assessors, NGO, Ulaanbaatar, Mongolia \\ Email: ikheco2565@gmail.com
}

How to cite this paper: Batmunkh, I. (2021) Environmental Issues in the Mining Sector of Mongolia. Journal of Environmental Protection, 12, 415-427. https://doi.org/10.4236/jep.2021.126025

Received: May 23, 2021

Accepted: June 26, 2021

Published: June 29, 2021

Copyright $\odot 2021$ by author(s) and Scientific Research Publishing Inc. This work is licensed under the Creative Commons Attribution International License (CC BY 4.0).

http://creativecommons.org/licenses/by/4.0

\begin{abstract}
This research is the summary of the results of the environmental damage assessment and rehabilitation cost estimation works carried out involving in total, 242 gold-placers' licensed areas, within the framework of implementation of the "Law on Prohibiting Exploration and Mining of Minerals at Sources of Rivers and Streams, within Protected zones of Water basins and Forest funds", adopted by the Parliament of Mongolia, in 2009.
\end{abstract}

\section{Keywords}

Environmental Damage and Its Rehabilitation, Open Water Sources, Protection Zones with Water Basins and Forest Funds

\section{The Results of the Environmental Damage Estimation}

Distortion emerged in the mining industry development has covered an extremely wide range by creating an irrecoverable environmental hazard or risk as a result of excavating and destroying lands at many locations in several aimags and soums. Such a situation has created a necessity for implementing a substantial principled action by the government. For this reason, there was approved by the Parliament of Mongolia the "Law on Prohibiting exploration and mining of mineral resources at sources of rivers and streams, within a protection zone of areas with water basins and in areas with forest funds" which is commonly called the long-name law. In the framework of implementation of the law, upon the resolution \#174, June 08, 2010 of the Mongolian Government, the licenses of mining entities operating within the legally prohibited zones were revoked.

Further, again in the framework of implementation of the law and program, in 2011, the work of assessing the environmental damage caused by mining at the gold-placers located at the sources of rivers and streams, within the protec- 
tion zones of areas with water basins and in the areas with forest funds, and estimating relevant rehabilitation costs was organized by the Ministry of Nature, Environment and Tourism/MNET/jointly with the professional environmental impact assessment companies.

Prior to commencing the work of assessing the environmental damage and estimating relevant rehabilitation costs, the professional environmental assessment companies visited to the project-proponent entities (mining entities) to explain and introduce the aim and importance of their work, get acquainted with necessary documents, and make the entities complete the relevant assessment-related materials. In the frame of this work, from July through September 2011, the experts of the environmental companies conducted the field surveys at their allotted areas by performing detailed on-the-spot measurements to identify the extent and category of damaged lands. The water and soil samples were taken at the required points and analyzed at the professional accredited laboratories.

The professional environmental impact assessment companies performed the assessment of environmental damage caused by the mining operation at the special mining license plots located within the protection zones of areas with river sources and water basins and in the areas with forest funds and identified the volume of relevant rehabilitation work in accordance with the "methodology for assessing environmental damage and calculating relevant compensation" approved by the Order A-156 of the Minister of Nature, Environment and Tourism dated May 27, 2010 [1], and estimated the relevant rehabilitation costs in accordance with the "methodology for performing the technical and biological reclamations at lands damaged by mining activity" approved by the Order 417 of the Minister of Nature, Environment and Tourism dated December 29, 2009 [2], respectively.

This article uses the results of the "integrated report of the Work of assessing the environmental damage caused by gold mining at sources of rivers and streams, within a protection zone of areas with water basins and in areas with forest funds, and estimating relevant rehabilitation costs" [3].

\subsection{Lands Affected with Gold Mining, Extent of Its Damage}

Actually, $76.7 \%$ or 45.47 thousand hectares of the total 59.27 thousand hectares (thsnd.ha) of mining license area involved in the field survey conducted in the frame of the work of assessing the environmental damage and estimating relevant rehabilitation costs, are included in the zones legally prohibited by the "Law on Prohibiting exploration and mining of mineral resources at sources of rivers and streams, within a protection zone of areas with water basins and in areas with forest funds". In addition, $21.2 \%$ or 12.56 thsnd.ha of the total mining license area were not developed that time, while $19.9 \%$ or 9.05 thsnd.ha of the license plots within the legally prohibited zones were not also operated.

On the scale of the total mining license areas the licenses of which were revoked, 5.08 thsnd.ha of land were affected and damaged by the gold mining, 
while such a damaged land covers 4.79 thsnd.ha within the legally prohibited zones. If to consider the land damage emerged as a result of the gold-placer mining by geographic zones, $26.8 \% ; 26.8 \% ; 25.8 \%$, and $8.2 \%$ of the total damaged lands are allotted to the Zaamar zone; Arkhangai and Uvurkhangai aimags; Selenge aimag, and Darkhan-Uul aimag, respectively. Then, out of the damaged lands within the legally prohibited zones, 34.7\%; 16.28\%; 30.28\%; 9.41\%; 7.63\%; $1.71 \%$, and $0.37 \%$ belong to the territories of Selenge aimag; Zaamar zone; Arkhangai and Uvurkhangai aimags; Bayankhongor aimag; Darkhan-Uul aimag; Khentii and Dornod aimags, and the territories of Uvs and Khuvsgul aimags, respectively.

The gold-placers involved in the work of assessing the environmental damage and estimating the rehabilitation costs are either located in a single zone or within 2 - 3 overlapping zones legally prohibited by the long-name law. Area with gold-placers covers 21.1 thsnd-ha at the sources of rivers and streams, while such areas cover 14.8 thsnd.ha and 7.9 thsnd.ha within the protection zone of water basins and in the area with forest funds, respectively. Then, the maximal coincidence covering 7.99 thsnd.ha area was revealed at the sources of rivers and in the areas with forest funds, while the coincidence within 1.1 thsnd.ha was identified within the water basin protection zone and in the areas with forest funds. If 427.4 hectares of gold-placer license area are overlapped at the sources of rivers and within the water basin protection zones, the minimal area of coincidence covering 400.64 hectares is allotted to the sources of rivers, the water basin protection zones and the areas with forest funds.

As shown in Table 1, of the total 5085.52 hectares of land damaged within the mining license areas, 4778.84 hectares of land have been damaged within the legally prohibited zones, while the area of land disturbed outside the mining license plots accounts for 711.76 hectares.

Table 1. Areas of damaged lands identified by their geographic zones and locations, ha.

\begin{tabular}{|c|c|c|c|c|c|c|c|c|}
\hline \multirow{3}{*}{ No. } & \multirow{3}{*}{ Regions and zones } & \multirow{3}{*}{$\begin{array}{l}\text { Total area } \\
\text { damaged by } \\
\text { mining, ha }\end{array}$} & \multicolumn{6}{|c|}{ Of these: By location of damage } \\
\hline & & & \multicolumn{2}{|c|}{$\begin{array}{l}\text { Within the } \\
\text { mining } \\
\text { license areas }\end{array}$} & \multicolumn{2}{|c|}{$\begin{array}{l}\text { Within the } \\
\text { legally } \\
\text { prohibited zones }\end{array}$} & \multicolumn{2}{|c|}{$\begin{array}{l}\text { Outside the } \\
\text { mining } \\
\text { license areas }\end{array}$} \\
\hline & & & ha & percent & ha & percent & ha & percent \\
\hline 1 & Khangai region & 2101.60 & 1401.44 & 66.7 & 1446.94 & 68.8 & 240.93 & 11.5 \\
\hline 2 & Zaamar zone & 2185.01 & 1127.59 & 51.6 & 778.05 & 35.6 & 75.47 & 3.5 \\
\hline 3 & Bayankhongor aimag & 699.61 & 358.65 & 51.3 & 449.82 & 64.3 & 9.13 & 1.3 \\
\hline 4 & Darkhan-Uul aimag & 547.03 & 341.48 & 62.4 & 364.65 & 66.7 & 140.37 & 25.7 \\
\hline 5 & Selenge aimag & 2186.33 & 1533.27 & 70.1 & 1628.23 & 74.5 & 221.69 & 10.1 \\
\hline 6 & Tuv aimag & 34.73 & 13.11 & 37.2 & 12.00 & 34.1 & 0.9 & 4.1 \\
\hline 7 & Western region & 251.09 & 244.10 & 97.2 & 17.61 & 7.0 & 0.00 & 0.0 \\
\hline 8 & Eastern region & 142.18 & 65.88 & 46.3 & 81.54 & 57.3 & 23.24 & 16.3 \\
\hline \multirow{2}{*}{ Total } & ha & 8147.58 & 5085.52 & 62.4 & 4778.84 & 58.6 & 711.76 & 8.7 \\
\hline & percent & 100.0 & 62.4 & & 58.6 & & 8.7 & \\
\hline
\end{tabular}


Judging from the assessment of the total environmental damage caused by the gold mining by each of environmental components conducted in accordance with the "Methodology for assessing environmental damage and calculating relevant compensation", the assessment of damage caused to the surface water was identified the highest that it accounts for $72.0 \%$ of the total environmental damage. This is because most of the gold-placers are located within the river valleys and use a great amount of surface water in the gold-washing work. The damage caused to the surface water was identified highest in the Zaamar zone because the gold mining entities operating there draw the water from the Tuul River to create an artificial pool.

According to Table 2, $150 \mathrm{~km}$ of the total $256 \mathrm{~km}$ long riverbed within the licensed areas has been affected by the mining operations, of which just $10.2 \mathrm{~km}$ has been rehabilitated.

\subsection{Environmental Damage}

According to the relevant estimation of environmental damage, in total 8.15 thsnd.ha of land were damaged with the mining activity performed within the mining license areas and as a result, the loss of MNT 1.16 trillion were caused to the environment. Out of the total environmental loss, $59.1 \%$ is allotted to the Zaamar zone.

The extent of environmental damage caused by gold mining is shown in $\mathrm{Ta}$ ble 3 .

Structure of environmental damage. Judging from the assessment of the environmental damage separately by each of the ecosystem components, the damage to the surface water accounts for nearly $90 \%$ of the total environmental damage in the Zaamar zone, while the damages to the plant cover and the soil mantle account approx. for $50 \%$ and $30 \%$ in the Eastern region and Selenge aimag, respectively. It is clearly seen that the difference in the environmental assessment in the regions is dependent on the specific features of each region and its environmentally valuable elements (water, soil, forest, flora, etc.).

Table 2. Riverbed impacts caused by gold-mining.

\begin{tabular}{lcccccc}
\hline & & Total length of & \multicolumn{4}{c}{ Measurements made at riverbeds } \\
\cline { 4 - 7 } No. & Regions/zones & $\begin{array}{c}\text { rivers passing } \\
\text { through the } \\
\text { license areas, } \mathrm{m}\end{array}$ & $\begin{array}{c}\text { Riverbed not } \\
\text { affected with } \\
\text { mining, } \mathrm{m}\end{array}$ & $\begin{array}{c}\text { Riverbed } \\
\text { affected with } \\
\text { mining, } \mathrm{m}\end{array}$ & $\begin{array}{c}\text { Diverted } \\
\text { riverbed, } \\
\mathrm{m}\end{array}$ & $\begin{array}{c}\text { Rehabilitated } \\
\text { riverbed, } \mathrm{m}\end{array}$ \\
\hline 1 & Khangai region & 106,660 & 46,160 & 60,500 & 14,930 & \\
2 & Zaamar zone & 25,699 & 23,262 & 13,784 & 3800 & \\
3 & Bayankhongor aimag & 27,950 & 4900 & 23,050 & 19,495 & 6320 \\
4 & Darkhan-Uul aimag & 45,133 & 21,637 & 22,416 & 2060 & 678 \\
5 & Selenge aimag & 35,025 & 12,750 & 24,975 & 11,530 & 3200 \\
6 & Tuv aimag & 675 & 480 & 195 & & \\
7 & Eastern region & 14,900 & 9750 & 5150 & 1010 & \\
& TOTAL & $\mathbf{2 5 6 , 0 4 2}$ & $\mathbf{1 1 8 , 9 3 9}$ & $\mathbf{1 5 0 , 0 7 0}$ & $\mathbf{5 2 , 8 2 5}$ & $\mathbf{1 0 , 1 9 8}$ \\
\hline
\end{tabular}


Table 3. Assessment of environmental damage caused by gold mining.

\begin{tabular}{ccccc}
\hline \multirow{2}{*}{ No. } & Regions/zones & $\begin{array}{c}\text { Total area damaged } \\
\text { with mining, ha }\end{array}$ & \multicolumn{2}{c}{ Total environmental damage } \\
\cline { 4 - 5 } & & 2101.60 & Million tugrig & Percent \\
\hline 1 & Khangai region & 2185.01 & $686,688.5$ & 19.3 \\
2 & Zaamar zone & 699.61 & $57,579.1$ & 59.1 \\
3 & Bayankhongor aimag & 547.03 & $33,594.4$ & 5.0 \\
4 & Darkhan-Uul aimag & 2186.33 & $149,622.6$ & 2.9 \\
5 & Selenge aimag & 34.73 & 406.1 & 12.9 \\
6 & Tuv aimag & 251.09 & 290.1 & 0.0 \\
7 & Western region & 142.18 & 8714.0 & 0.0 \\
8 & Eastern region & $\mathbf{8 1 4 7 . 5 8}$ & $1,161,451.8$ & 0.8 \\
& TOTAL & &
\end{tabular}

Figure 1 shows the extent of damage caused to the protection zones with forest funds and water sources.

Damage caused to the land plots and entrails of the earth. In total, 8147.58 hectares of land were affected and damaged with the gold-placer mining and the excavations and quarries occupy $21.1 \%$ of these damaged lands. The damage caused to the entrails of the earth account for $5.8 \%$ of the total environmental damage. If to judge the damage regionally, the damage to the entrails of the earth was identified maximal in Selenge aimag that it is estimated by MNT 28.2 billion and accounts for $40.0 \%$ of the total damage to the entrails of the earth.

According to Figure 2, the damage to the entrails of the earth within the Zaamar zone is estimated by MNT 16.5 billion, which accounts for $25.0 \%$ of the total damage of this type. Then, the damages to the earth entrails in Tuv aimag, and in the Western and Eastern regions range between MNT 49.6 - 589.2 millions, they don't even make up $2.0 \%$ of the total damage.

Damage to the surface and ground waters. The total area with river/stream sources and water basins where the mining activity is prohibited by the Mongolian "Law on Prohibiting exploration and mining of mineral resources at sources of rivers and streams, within a protection zone of areas with water basins and in areas with forest funds" covers 35.9 thsnd.ha in total.

As shown in Table 4, out of the above area, 14.6 thsnd.ha belong to Bayankhongor aimag, while 11.5 thsnd.ha and 7.2 thsnd ha belong to the Khangai region and the Zaamar zone, respectively. If to judge by the regions, the damage caused to the surface and ground waters is identified maximal in the Zaamar zone and Khangai region (Arkhangai and Uvurkhangai aimags), which accounts for $75.0 \%$ of the total damage to the water resource.

Damage to the forest funds. The protected zone with forest funds where the mining activity is legally prohibited covers 17.4 thsnd.ha in total, and out of these, $45.8 \%$ or 7.98 thsnd.ha are involved in the territory of Selenge aimag, while $29.8 \%$ (or 5.2 thsnd.ha); $9.6 \%$ (or 1.7 thsnd.ha), and $7.5 \%$ (or 1.3 thsnd.ha) 


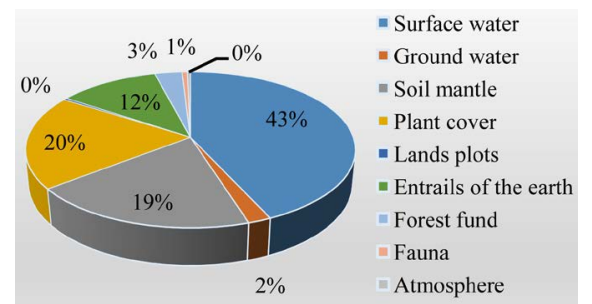

(a)

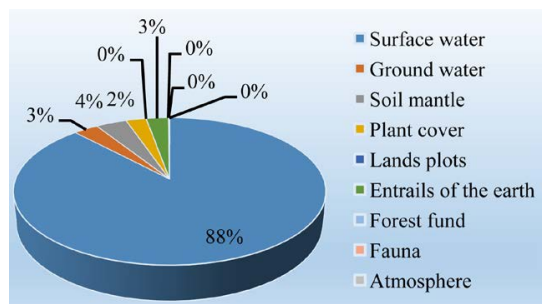

(b)

Figure 1. Structure of environmental damage within the legally prohibited zones. (a) Structure of environmental damage in a protected zone predominated with forest funds; (b) Structure of environmental damage in a protected zone predominated with water flows.
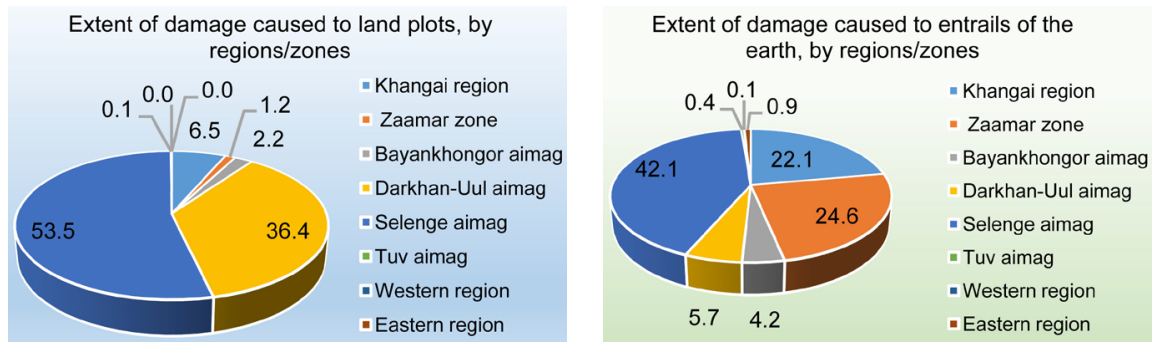

Figure 2. Damage caused to the land plots and entrails of the earth.

Table 4. Extent of damage caused to the surface and ground waters.

\begin{tabular}{lcccccc}
\hline No. & Regions/Zones & $\begin{array}{c}\text { Assessment of } \\
\text { total damage, }\end{array}$ & \multicolumn{2}{c}{$\begin{array}{c}\text { Damage to the } \\
\text { surface water }\end{array}$} & \multicolumn{2}{c}{$\begin{array}{c}\text { Damage to the } \\
\text { ground water }\end{array}$} \\
\cline { 6 - 7 } & & million tug. & million tug. & $\begin{array}{c}\text { Portion in } \\
\text { total damage }\end{array}$ & million tug. & $\begin{array}{c}\text { Portion in } \\
\text { total damage }\end{array}$ \\
\hline 1 & Khangai region & $224,557.0$ & $128,496.2$ & 57.2 & 5384.2 & 2.4 \\
2 & Zaamar zone & $686,688.5$ & $611,862.4$ & 89.1 & $21,147.3$ & 3.1 \\
3 & Bayankhongor aimag & $57,579.1$ & $49,432.5$ & 85.9 & 1206.0 & 2.1 \\
4 & Darkhan-Uul aimag & $33,594.4$ & $15,721.6$ & 46.8 & 1108.6 & 3.3 \\
5 & Selenge aimag & $149,622.6$ & $31,682.1$ & 21.2 & 1536.1 & 1.0 \\
6 & Tuv aimag & 406.1 & 5.4 & 1.3 & 82.4 & 20.3 \\
7 & Western region & 290.1 & 88.9 & 30.6 & & 0.0 \\
8 & Eastern region & 8714.0 & 2338.4 & 26.8 & 89.9 & 1.0 \\
\hline
\end{tabular}

are allotted to the Khangai region; Darkhan-Uul aimag, and the Zaamar zone, respectively. Then, the rest $5.6 \%$ (or 1.0 thsnd.ha) are located in the Western and Eastern regions. As for Bayankhongor aimag, there wasn't considered any area with forest funds in the frame of the work of assessing the environmental damage. According to the results of the work of estimating the environmental damage, it was identified that the damage amounting MNT 12.8 billion in total was caused to the forest funds as a result of gold-placer mining. 
As shown in Table 5, out of the total damage to the forest funds, $88.5 \%$ are solely allotted to Selenge aimag, while $8.6 \% ; 1.9 \%$, and $0.2 \%$ are allotted to Darkhan-Uul aimag, the Khangai region and the Eastern region, respectively.

Damage to the soil mantle. The amount of damage caused to the soil mantle totals MNT 107.4 billion and it accounts for $9.3 \%$ of the total damage. As shown in Table 6, amount of damage caused to 1.0 hectare of soil mantle is estimated MNT 13.2 million in average, and the assessment of damage of the soil within a unit area ranges between MNT $0.4-18.8$ million by the regions/zones.

Damage caused to the plant cover. Judging from the results of the assessment of the environmental damage caused by the gold-placer mining, the amount of damage caused to the plant-cover accounts for $8.5 \%$ of the total environmental damage. The damage to the plant-cover differs from region to region.

Table 5. Damage to the woods and forest funds, by regions/zones.

\begin{tabular}{|c|c|c|c|c|}
\hline \multirow{2}{*}{ No. } & \multirow{2}{*}{ Regions/zones } & \multirow{2}{*}{$\begin{array}{l}\text { Assessment of } \\
\text { environmental damage, } \\
\text { million tug. }\end{array}$} & \multicolumn{2}{|c|}{$\begin{array}{c}\text { Amount of damage caused to } \\
\text { the forest fund }\end{array}$} \\
\hline & & & Million tug. & $\begin{array}{l}\text { Portion in } \\
\text { total damage }\end{array}$ \\
\hline 1 & Khangai region & $224,557.0$ & 249.1 & 0.1 \\
\hline 2 & Zaamar zone & $686,688.5$ & 94.3 & 0.0 \\
\hline 3 & Bayankhongor aimag & $57,579.1$ & - & \\
\hline 4 & Darkhan-Uul aimag & $33,594.4$ & 1098.0 & 3.3 \\
\hline 5 & Selenge aimag & $149,622.6$ & $11,344.2$ & 7.6 \\
\hline 6 & Tuv aimag & 406.1 & - & \\
\hline 7 & Western region & 290.1 & - & \\
\hline \multirow[t]{2}{*}{8} & Eastern region & 8714.0 & 31.0 & 0.4 \\
\hline & TOTAL & $1,161,451.8$ & $12,816.7$ & 1.1 \\
\hline
\end{tabular}

Table 6. Amount of damage caused to the soil mantle.

\begin{tabular}{|c|c|c|c|c|c|}
\hline & \multirow{2}{*}{ Regions/zones } & \multirow{2}{*}{$\begin{array}{c}\text { Assessment of } \\
\text { total damage, } \\
\text { million tug. }\end{array}$} & \multicolumn{2}{|c|}{$\begin{array}{l}\text { Amount of damage } \\
\text { caused to soil mantle }\end{array}$} & \multirow{2}{*}{$\begin{array}{c}\text { Assessment of } \\
\text { damage caused } \\
\text { to } 1.0 \text { ha of soil } \\
\text { mantle, million tug. }\end{array}$} \\
\hline & & & million tug. & percent & \\
\hline 1 & Khangai region & $224,557.0$ & $30,323.0$ & 13.5 & 15.1 \\
\hline 2 & Zaamar zone & $686,688.5$ & $24,468.7$ & 3.6 & 11.2 \\
\hline 3 & Bayankhongor aimag & $57,579.1$ & 2379.1 & 4.1 & 3.4 \\
\hline 4 & Darkhan-Uul aimag & $33,594.4$ & 7598.1 & 22.6 & 13.9 \\
\hline 5 & Selenge aimag & $149,622.6$ & $41,057.9$ & 27.4 & 18.8 \\
\hline 6 & Tuv aimag & 406.1 & 52.4 & 12.9 & 1.5 \\
\hline 7 & Western region & 290.1 & 109.4 & 37.7 & 0.4 \\
\hline \multirow[t]{2}{*}{8} & Eastern region & 8714.0 & 1454.8 & 16.7 & 10.2 \\
\hline & Total & $1,161,451.8$ & $107,443.5$ & 9.3 & 13.2 \\
\hline
\end{tabular}


Amount of the plant-cover damage in the Eastern region (Khentii and Dornod aimags) is estimated by MNT 4.2 billion and if to consider by the area of the damaged land, the damage caused to 1.0 ha of land is assessed by MNT 31.1 million which is the highest assessment among the other regions. As for the Khangai region (Arkhangai and Uvurkhangai aimags), the total assessment of the damage caused to the plant cover was estimated by MNT 44.4 billion while this index in Selenge aimag was identified as MNT 32.1 billion. Thus, in above aimags, the assessment of damage caused to 1.0 ha of land ranges between MNT 22.1 - 32.9 billion in average and the assessment of plant cover damage in the aimags accounts nearly for $60.0 \%$ of the total plant-cover assessment.

Judging from Table 7, the total amount of damage caused to the plant-cover in the Khangai region, Selenge and Darkhan-Uul aimags, and the Eastern region is estimated as MNT 79.0 billion which accounts for over $80.0 \%$ of the total damage. It additionally shows that the wooded territories with rich forest funds are also characterized with abundant vegetation cover.

\subsection{Environmental Damage Caused to the Legally Prohibited Zones}

The total area of the gold-placers located at the sources of rivers and streams, within the protection zones of areas with water basins and in the areas with forest funds, the mining licenses of which were revoked, covers 45.9 thsnd.ha area involving 4778.84 hectares of damaged land. Besides, as it was identified 711.76 hectares of land outside the licensed plots were also damaged by the gold mining entities. So, in the assessment, the damage caused to the lands outside the license plots were added to the area of the lands damaged within the legally prohibited zones.

Judging from Table 8, the total amount of environmental damage is estimated MNT 1.16 trillion and of these, the amount of damage allotted to the legally prohibited zones makes up MNT 672 billion.

Table 7. Amount of damage caused to the plant cover.

\begin{tabular}{lcccc}
\hline No & Regions/zones & $\begin{array}{c}\text { Assessment of } \\
\text { total damage } \\
\text { million tug. }\end{array}$ & $\begin{array}{c}\text { Assessment of damage } \\
\text { caused to the plant cover }\end{array}$ & percent \\
\cline { 3 - 4 } 1 & Khangai region & $224,557.0$ & $44,442.4$ & 19.8 \\
2 & Zaamar zone & $686,688.5$ & $12,491.3$ & 1.8 \\
3 & Bayankhongor aimag & $57,579.1$ & 1716.7 & 3.0 \\
4 & Darkhan-Uul aimag & $33,594.4$ & 3237.5 & 9.6 \\
5 & Selenge aimag & $149,622.6$ & $32,102.6$ & 21.5 \\
6 & Tuv aimag & 406.1 & 7.3 & 1.8 \\
7 & Western region & 290.1 & 12.4 & 4.3 \\
8 & Eastern region & 8714.0 & 4194.4 & 48.1 \\
\hline
\end{tabular}


Table 8. Assessment of environmental damage caused to the legally prohibited zones.

\begin{tabular}{|c|c|c|c|c|c|}
\hline \multirow[t]{2}{*}{ No. } & \multirow{2}{*}{ Regions/zones } & \multirow{2}{*}{$\begin{array}{l}\text { Assessment of } \\
\text { total damage, } \\
\text { million tug. }\end{array}$} & \multicolumn{2}{|c|}{$\begin{array}{l}\text { Damage caused to the legally } \\
\text { prohibited zones, million tug. }\end{array}$} & \multirow{2}{*}{$\begin{array}{c}\text { Portion in } \\
\text { total damage, } \\
\%\end{array}$} \\
\hline & & & million tug. & percent & \\
\hline 1 & Khangai region & $224,557.0$ & $212,086.1$ & 31.6 & 94.4 \\
\hline 2 & Zaamar zone & $686,688.5$ & $223,946.2$ & 33.3 & 32.6 \\
\hline 3 & Bayankhongor aimag & $57,579.1$ & $57,579.1$ & 8.6 & 100.0 \\
\hline 4 & Darkhan-Uul aimag & $33,594.4$ & $29,937.8$ & 4.5 & 89.1 \\
\hline 5 & Selenge aimag & $149,622.6$ & $139,052.7$ & 20.7 & 92.9 \\
\hline 6 & Tuv aimag & 406.1 & 406.1 & 0.1 & 100.0 \\
\hline 7 & Western region & 290.1 & 290.1 & 0.0 & 100.0 \\
\hline \multirow[t]{2}{*}{8} & Eastern region & 8714.0 & 8714.0 & 1.3 & 100.0 \\
\hline & TOTAL & $1,161,451.8$ & $672,012.1$ & 100.0 & 57.9 \\
\hline
\end{tabular}

If to have a look at the damage by each of environmental components, the amount of damage caused to the atmosphere makes up MNT 1.96 billion, while the damages of 839.6 billion; 30.5 billion; 107.4 billion; 98.2 billion; 1.66 billion; 67.0 billion; 12.8 billion, and 3.3 billion are allotted to surface water; ground water; soil mantle; plant cover; land plots; entrails of the earth; forest fund, and fauna, respectively.

\section{Reclamation of Damaged Lands, Estimation of Costs for Its Implementation}

As it was identified during the field survey, out of the total 8147.58 hectares of damaged land, the technical and biological reclamations were made just at 2097.8 and 632.2 hectares, respectively. It means the technical reclamation was made for $25.7 \%$ and the biological reclamation-for $7.8 \%$ of the total damaged area and this is an absolutely inadequate index.

As shown in Table 9, the surface for $76.8 \%$ of the total area involved in the reclamation was shaped up by technical reclamation, while the surface for $23.2 \%$ was shaped and then vegetated through biological reclamation. The area involved in vegetation accounts for $7.7 \%$ of the total damaged area.

\section{Identification of Area Required to Be Reclaimed and Calculation of Reclamation Costs}

Currently, a major portion of the lands damaged under the impact of gold mining remains damaged as before. So, as it was estimated 7096.1 hectares of land are required to be reclaimed. Prior to fully involve above area in the biological reclamation, first it is required to implement the technical reclamation at 5057.1 hectares of land.

According to the preliminary estimation, in total, an amount of MNT 59.18 billion will be required for land reclamation within the legally prohibited zones; 
Table 9. Areas damaged and/or reclaimed.

\begin{tabular}{|c|c|c|c|c|c|c|}
\hline \multirow{2}{*}{ No. } & \multirow{2}{*}{ Regions/zones } & \multirow{2}{*}{$\begin{array}{c}\text { Total area } \\
\text { damaged, } \\
\text { ha }\end{array}$} & \multirow{2}{*}{$\begin{array}{l}\text { Area identified } \\
\text { as damaged in } \\
\text { course of the } \\
\text { survey, ha }\end{array}$} & \multirow{2}{*}{$\begin{array}{c}\text { Area } \\
\text { reclaimed, } \\
\text { ha }\end{array}$} & \multicolumn{2}{|c|}{ Of these: } \\
\hline & & & & & Technical & Biological \\
\hline 1 & Khangai region & 2101.6 & 1567.26 & 459.23 & 454.43 & 4.8 \\
\hline 2 & Zaamar zone & 2185.01 & 1225.16 & 982.91 & 657.18 & 325.73 \\
\hline 3 & Bayankhongor aimag & 699.61 & 233.14 & 586.35 & 394.81 & 191.54 \\
\hline 4 & Darkhan-Uul aimag & 547.03 & 373.4 & 103.46 & 76.47 & 26.99 \\
\hline 5 & Selenge aimag & 2186.33 & 1412.63 & 516.8 & 433.66 & 83.14 \\
\hline 6 & Tuv aimag & 34.73 & 14.05 & 21.2 & 21.2 & 0 \\
\hline 7 & Western region & 251.09 & 244.13 & 6.99 & 6.99 & 0 \\
\hline \multirow[t]{2}{*}{8} & Eastern region & 142.18 & 81.03 & 53.06 & 53.06 & 0 \\
\hline & TOTAL & 8147.62 & 5150.78 & 2730 & 2097.8 & 632.2 \\
\hline
\end{tabular}

of these, $64.9 \%$ shall be spent on technical reclamation and $24.1 \%$-on biological reclamation. As it is predicted the cost of land reclamation within the legally prohibited zones in the Zaamar zone is likely to be MNT 11.03 billion that is $43.4 \%$ of the total cost of land reclamation required to be implemented throughout the Zaamar zone as shown in Table 10.

If to consider by zoning, the mining license plots in Bayankhongor and Tuv aimags, and the Eastern region (Khentii and Dornod aimags) are wholly included in the legally prohibited zones, and consequently, for these aimags, the cost of land reclamation within the legally prohibited zones equals to the total cost of land reclamation. Then, for the Western region, the cost of land reclamation within the legally prohibited zones is likely to be wholly spent on biological reclamation.

The cost of reclamation is estimated maximal (MNT 25.4 billion) for the Zaamar zone. As for the Zaamar zone, the area required to be reclaimed is less than that in the Khangai region by over 165 hectares, however, the cost of reclamation exceeds the cost of reclamation required for the Khangai region by MNT 2.7 billion. According to the preliminary estimation, in the Zaamar zone, $80.7 \%$ of the total reclamation cost is expected to be spent on technical reclamation.

A total amount required for reclamation of damaged lands is MNT 86.3 billion; of these, 54.6 and 17.6 billion are expected to be spent on technical and biological reclamations, respectively. Besides, the amounts of 7.7 billion; 999.1 million, and 5.2 billion will be spent on riverbed reclamation; mining closure, and monitoring of reclamation, respectively. Out of the total reclamation cost, the amount of MNT 59.2 billion is expected to be allotted to the reclamation of the total damaged area within the legally prohibited zones. Of this amount, 22.8 billion; 17.7 billion, and 11.0 billion will be spent on forest fund rehabilitation; technical and biological reclamations, respectively. 
Table 10. Cost of reclamation to be implemented in the legally prohibited zones, million tug.

\begin{tabular}{|c|c|c|c|c|c|c|c|c|c|}
\hline \multirow[t]{2}{*}{ Regions/zones } & \multirow[t]{2}{*}{$\begin{array}{l}\text { Total cost, } \\
\text { million tug. }\end{array}$} & \multicolumn{5}{|c|}{$\begin{array}{c}\text { Total cost of reclamation } \\
\text { to be implemented in } \\
\text { the legally } \\
\text { prohibited zones }\end{array}$} & \multicolumn{2}{|c|}{ Of these: } & \multirow[b]{2}{*}{$\%$} \\
\hline & & $\begin{array}{l}\text { Technical } \\
\text { reclamation }\end{array}$ & $\begin{array}{l}\text { Biological } \\
\text { reclamation }\end{array}$ & Million tug. & $\%$ & $\begin{array}{l}\text { Technical } \\
\text { reclamation }\end{array}$ & $\%$ & $\begin{array}{l}\text { Biological } \\
\text { reclamation }\end{array}$ & \\
\hline Khangai region & $20,627.1$ & $12,666.9$ & 6572.3 & $17,663.0$ & 85.6 & $11,126.3$ & 87.8 & 5269.0 & 80.1 \\
\hline Zaamar zone & $25,403.5$ & $20,502.6$ & 2724.7 & $11,028.0$ & 43.4 & 7811.1 & 38.1 & 1806.4 & 66.3 \\
\hline Bayankhongor aimag & 5430.4 & 3316.5 & 874.9 & 5430.4 & 100.0 & 3316.5 & 100 & 874.9 & 100 \\
\hline Darkhan-Uul aimag & $10,740.0$ & 2952.7 & 653.5 & 3084.2 & 28.7 & 2262.6 & 76.6 & 416.3 & 63.7 \\
\hline Selenge aimag & $22,719.0$ & $14,437.8$ & 6253.1 & $20,713.2$ & 91.2 & $13,307.4$ & 92.2 & 5408.4 & 86.5 \\
\hline Tuv aimag & 69.4 & 27.1 & 39.1 & 69.4 & 100.0 & 27.1 & 100 & 39.1 & 100 \\
\hline Western region & 195.3 & 124.4 & 60.1 & 31.2 & 16.0 & - & & 28.7 & 47.8 \\
\hline Eastern region & 1158.2 & 589.19 & 455.3 & 1158.2 & 100.0 & 589.2 & 100 & 455.3 & 100 \\
\hline TOTAL & $86,342.9$ & $54,617.18$ & $17,632.8$ & $59,177.4$ & 68.5 & $38,440.1$ & 70.4 & $14,298.1$ & 81.1 \\
\hline
\end{tabular}

As a result of implementing the land reclamation mission perfectly, the gold mining entities shall bring a substantial contribution towards ensuring the implementation of the Mongolian "Law on Prohibiting exploration and mining of mineral resources at sources of rivers and streams, within a protection zone of areas with water basins and in areas with forest funds".

\section{Conclusions \& Recommendations}

1) The long name law which was adopted by the Parliament of Mongolia in 2010 and has been efficiently implemented by the Mongolian Government since that time could become a major action and/or significant document having specific importance for further development of the mining industry of Mongolia.

2) While the professional environmental companies were performing on-the-spot measurements in the frame of the work of assessing the environmental damage and estimating the rehabilitation costs, the number of license holding companies was added by one and totaled 138. In total, there were 239 licenses in the possession of these entities; of the companies, 115 were actively engaged in gold mining at 184 licensed plots while 23 license-holding entities hadn't ever run mining activity at their 42 licensed plots. Out of 115 operating entities, 113 were involved in the work of assessing the environmental damage and estimating the rehabilitation costs. Of these 113 entities, 111 were running mining activity within the legally prohibited zones. Judging from the integrated results of the measurements, in total, 8147.6 hectares of land were damaged; 5085.5 ha within the mining license areas, 4778.8 ha within the legally prohibited zones, and 711.8 ha outside the mining license areas.

3) The total amount of environmental damage is estimated by MNT 1.16 trillion, and of these, MNT 672.0 billion are allotted to the legally prohibited zones. 
If to have a look at the damage by each of environmental components, the amount of damage caused to the atmosphere makes up MNT 1.96 billion, while the damages of 839.6 billion; 30.5 billion; 107.4 billion; 98.2 billion; 1.66 billion; 67.0 billion; 12.8 billion, and 3.3 billion are allotted to surface water; ground water; soil mantle; plant cover; land plots; entrails of the earth; forest fund, and fauna, respectively.

4) In total, 7096.1 hectares of land are required to be reclaimed. It means first, it is required to implement the technical reclamation at 5057.1 hectares of land, and then, to involve the whole 7096.1 hectares of land in the biological reclamation. The total amount required for reclamation of damaged lands is MNT 86.3 billion; of these, 54.6 and 17.6 billion are expected to be spent on technical and biological reclamations, respectively. Besides, the amounts of 7.7 billion; 999.1 million, and 5.2 billion will be spent on riverbed reclamation; mining closure, and monitoring of reclamation, respectively. Out of the total reclamation cost, the amount of MNT 59.2 billion is expected to be allotted to the reclamation of the total damaged area within the legally prohibited zones. Of this amount, 22.8 billion; 7.7 billion; 17.7 billion, and 11.0 billion will be spent on forest fund rehabilitation; riverbed reclamation; technical and biological reclamations, respectively.

5) From this perspective, for the license holding entities, it is necessary to introduce and use internationally-recognized environmentally favorable modern advanced technologies in the gold mining activity, strictly adhere to the relevant technological sequences, and implement the land reclamation actions timely in strict accordance with the relevant standards. The time to learn and implement the practice of the responsible mining industries of the developed countries that use the natural resources properly for their further development and reclaim the mined sites thoroughly until they have no adverse environmental impact, has already come for the mining companies of our country.

6) This research is the first large-scale effort towards the application of the "Environmental Damage Assessment and Compensation Methodology" and will be an important step for addressing the issue of its integrated application and further improvement.

\section{Acknowledgements}

We would like to thank the staff of the Department of Environment and Natural Resources under the Ministry of Nature, Environment and Tourism for providing the opportunity to carry out this work. We also would like to express our highest gratitude to the professional environmental assessment companies, and environmental experts who participated in the effective implementation of this work, as well as to the experts of the Consulting Team who have monitored and consolidated the results of this work.

\section{Conflicts of Interest}

The author declares no conflicts of interest regarding the publication of this paper. 


\section{References}

[1] Methodology for Assessing Environmental Damage and Calculating Relevant Compensation. Approved by the Order A-156 of the Minister of Nature, Environment and Tourism, 27 May 2010.

[2] Methodology for Performing the Technical and Biological Reclamations at Lands Damaged by Mining Activity. Approved by the Order 417 of the Minister of Nature, Environment and Tourism, 29 December 2009.

[3] Integrated Report of the "Work of Assessing the Environmental Damage Caused by Gold Mining at Sources of Rivers and Streams, within a Protection Zone of Areas with Water Basins and in Areas with Forest Funds, and Estimating Relevant Rehabilitation Costs". UB, 2012. 